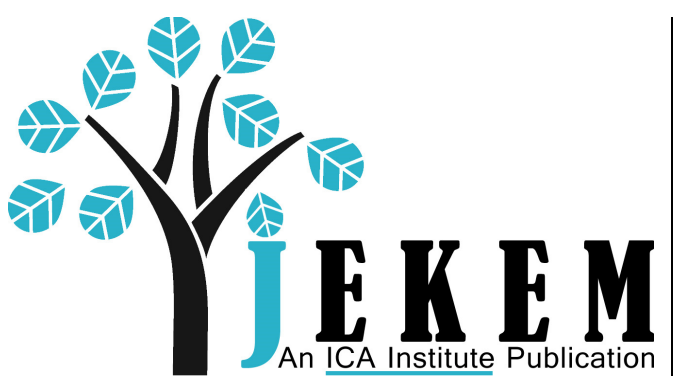

1549 CLAIRMONT ROAD, SUITE 202 • DECATUR, GA 30033 USA WWW.ICAINSTITUTE.ORG

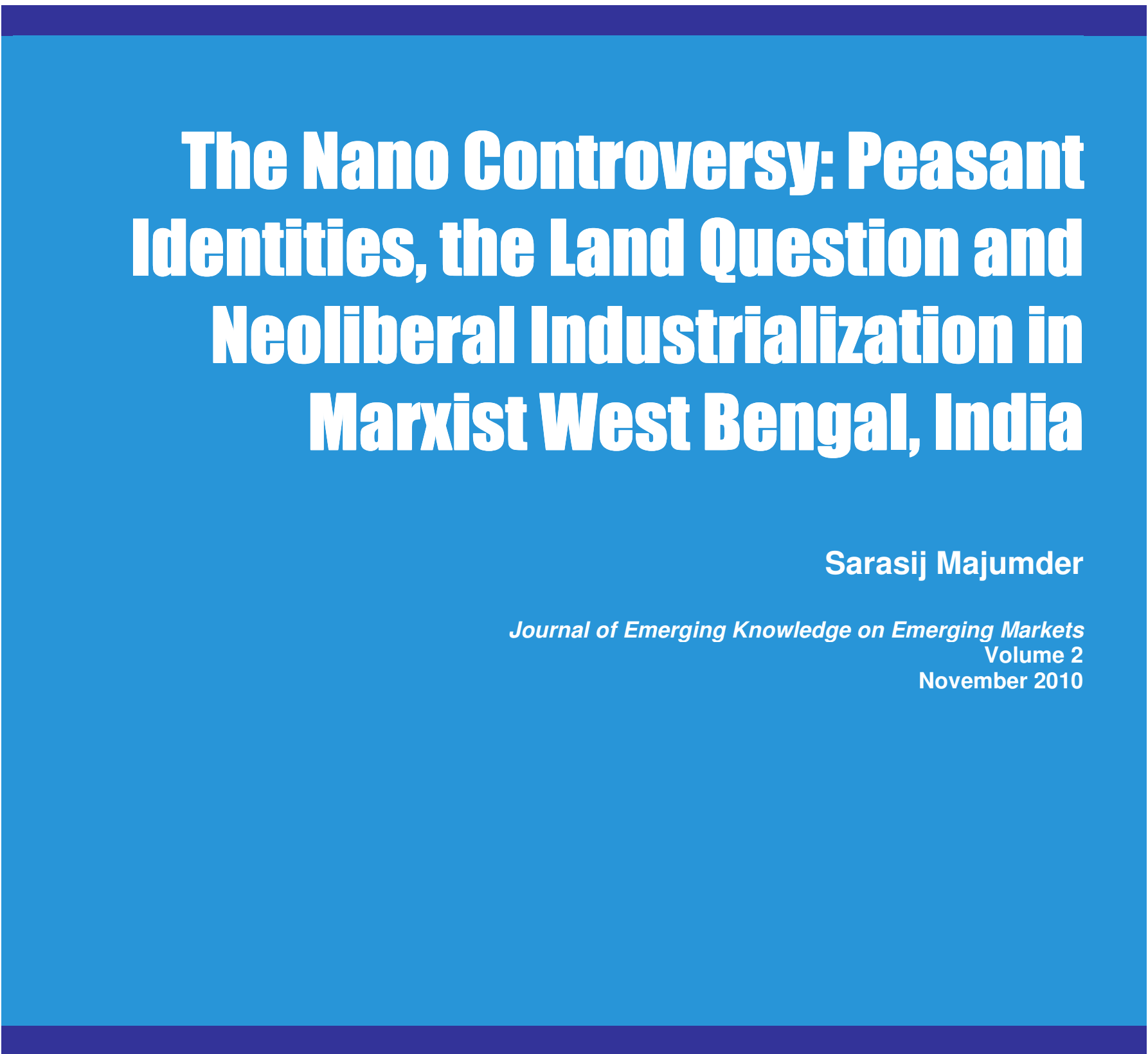




\title{
The Nano Controversy: Peasant Identities, the Land Question and Neoliberal Industrialization in Marxist West Bengal, India'
}

\author{
Sarasij Majumder \\ Kennesaw State University
}

Journal of Emerging Knowledge on Emerging Markets

Volume 2

November 2010

\begin{abstract}
s India undergoes a fast paced industrialization backed by liberalization policies of the central government, the land question has emerged as a key political issue in India. Provinces keep competing among each other to court private investors who seek large stretches of land for setting up export-oriented factories. This competition has been identified as one of the chief characteristics of "neoliberal industrialization" or "neoliberal globalization" by anthropologists, such as John Gledhill (1998: 12) and by geographers, such as David Harvey (1989). Such competition, they have claimed, helps big corporations to maximize profits in low-wage production sites where investors are promised tax-free entry.
\end{abstract}

Since 2006, the land and the industrialization questions in India have got a new twist because the Marxist government in West Bengal, known for its pro-peasant land

${ }^{1}$ The research was funded by American Institute of Indian Studies and United States National Science Foundation (NSF DDIG: 612845). 
redistribution policies made news regarding forcible acquisition of land ${ }^{2}$ from the protesting small-landholding peasants in Singur in West Bengal. The acquired land was given on a lease to Indian automaker Tata Motors to build a factory for its cheapest car Nano. The ultra-left parties, activists and left leaning intellectuals and the main opposition party in the province Trinamul Congress (TMC) criticized the ruling Marxists in West Bengal for their dealings with the Tata Company. They saw the land acquisition from the so-called "peasants" through the application of the eminent domain act as a violation not only of democracy but also of Marxist ideals. Thus like the Nano, which came to stand for the globalization or industrialization or the foreign or bideshi, ${ }^{3}$ the iconic figure of the peasant also became equally charged with meanings that signified the authentic, local, natural and son of the soil or earth. Nano became the opposite of the peasant and vice-versa.

As the peasant-Nano opposition suggests, urban activists and intellectuals dubbed the movement against the land acquisition and building of the factory as a complete rejection of globalization and industrialization. This paper contests these public images of the protests against land acquisition by drawing attention to certain paradoxes that the Singur case presents (which I discuss below).

I address these paradoxes through an ethnography done in villages where the controversy and the protests took place for two years (2006-2008). My ethnography ${ }^{4}$ suggests a perspective on protests against land acquisition in India, which is different from the usual narrative of capitalist industrialization and globalization that Marxists, such as David Harvey $(2007,2008)$ has put forward.

Harvey's narrative is a top-down imposition of capitalism by the state on its poorer citizens or villagers whose rights are not well guaranteed. I contend that we need to look at responses to globalization and neoliberalism in India, especially protests over land acquisition, by foregrounding the caste and status differences among the villagers in which ownership of land plays a key role. Further, I argue that these differences and landownership have a bearing on villagers' subjectivities or self-understandings/self-images

\footnotetext{
${ }^{2}$ Monetary compensation was paid.

${ }^{3}$ Although the Tata Motors is an Indian company, the foreigner epithet was used as political rhetoric to emphasize the non-Bengali origin of the Tata Group and also to highlight the immorality of the government action.

${ }^{4}$ which constitutes of two-year long field-stay (2006-2008), participant observation of protest politics and interviews with small landholding villagers who were affected by the project of land acquisition and building of the factory in various ways
} 
and lifestyles that give rise to multiple demands - such as farm subsidies, non-farm employment or earning opportunities in factories, urbanization and also extension of agricultural land — on the state. These demands often can contradict each other because factories or roads have to be built on land and they may encroach upon some one's agricultural plots. State and urban middle-class discourses of improvement, development, and modernization and administrative strategies of the state or the regime, [which I call "governmentality," following anthropologist Aihwa Ong (2006: 12)] crucially influence these demands of the villagers.

These demands, desires and aspirations put villagers in ambivalent position vis-à-vis large capitalists i.e. they are both complicit with large capitalists and their projects and also resistant to them. Marxists geographers, such as Harvey $(2007,2008)$ and Left activists tend to emphasize and talk about the latter i.e. the resistance, which make their story one-sided. By shifting the focus to differences within the villagers, who are misrepresented by urban activists or ultra-Left politicians as a homogenous group of peasants and by turning the attention to identities and self-understandings associated with landownership, I complicate the Marxists theories of globalization, which see capital as an all-powerful entity that usurps and dispossesses powerless peasants. In Marxist theories of globalization of David Harvey, an eminent Marxist geographer, peasants are represented as homogenous groups devoid of any desires and aspirations for upward mobility and their protests are interpreted as simply anti-developmental or anti-capitalist. My aim is to add a certain degree of complexity to Harvey's theory of "accumulation through dispossession" i.e. capitalist accumulation proceeds by dispossessing the peasants of their land and resources and not to dismiss the formulation altogether. His formulation, I admit, has some explanatory power in the light of the ways in which land and other resources are appropriated by force in many countries, such as China, Mexico, Bolivia and also India. Nonetheless, we need to complicate the simple narrative of capitalist penetration and peasant victimization. This complication is necessary not to celebrate corporate capitalism but to understand global capitalism in its subtleties and intricacies.

Before, I discuss the paradoxes, I must mention that in popular discourses, the Marxist regime in West Bengal has been much and rightly criticized for corruption, party-based nepotism, mismanagement and authoritarian stand on the issue of land acquisition. But the general controversy over land acquisition and in particular the responses of villagers to acquisition of land for the Nano factory at Singur, brings up several issues and paradoxes, which require deeper analysis of how landownership shapes rural social relations and selfunderstanding of the villagers. The Singur case and general protests against land acquisition cannot be simply reduced to corruption, nepotism, or a dictatorial attitude of a regime, although this essay does not deny the presence of all those issues. Also simply corruption and mismanagement cannot be the only explanation because monetary compensation for 
each of the plots acquired in Singur was paid by checks issued by the government before the land was acquired (see Chart 1). Many villagers did not take checks in protest and many villagers took the checks, and cashed it but continued to protest. However, there were also a significant number of villagers who willingly took the checks, cashed it and gave up their land. Many protestors expressed their unhappiness over the amount given in the check but compensation amount and other kinds of rehabilitation never featured in the agenda of the opposition party, Trinamul Congress or the ultra-Leftists and urban activists because they demanded complete withdrawal of the project. But the withdrawal of the project paradoxically led to counter-protests to bring back the factory by raising slogans, such as "Come Back Nano" and "Welcome Ratan Tata." Therefore, we need to look closely at the paradoxes, which I present next.

\section{The Paradoxes}

The first one is a Marxist provincial regime's adoption of neoliberal industrial policy, although the regime and its members are critical of the neoliberal policies of the central government, such as privatizing big public sector companies and giving subsidies to the foreign and domestic multinationals. The West Bengal case may throw light on the political phenomenon, which has become very commonplace in Asia in the recent years. We have seen time and again regimes traditionally opposed to liberal policies, such as unregulated markets or democracy, have adopted neoliberal forms of industrialization. This coexistence of socialist formations with feverish capitalist activity is seen as an anomaly and has been explained in terms of double standards of the regime or leadership by the left liberal thinkers in the US. For example, David Harvey (2007) observed that Deng Xiaoping could be a secret "capitalist roader" to express the incomprehensibility of China's embracing of neoliberal economic reforms (120). Perry Anderson (2007) blames the new leadership of the Marxist regime to lament West Bengal's three decade-old left

\section{Chart 1: Highlights of the Acquisition}

- 997 acres of land acquired.

-12000 checks issued to compensate the landowners.

- Compensation was a little $(150 \%)$ more than the market rate

- 3000 checks issued to compensate the registered sharecroppers.

- Homesteads were not touched 
government's pro-reform position. Scale-wise, China and West Bengal cannot be compared. Yet the comments made by the left liberals are uncannily similar.

The second paradox is that despite protests there was a silent approval of the project because more than seven hundred villagers joined the workforce that built the boundary walls around the 1000 acres of land acquired by the government for the Tata factory and several thousands marched in a counter-protest to bring back the factory when it moved to Sanand in Gujarat. Such silent approval among many ordinary villagers surfaced only after Tata motors pulled out because of continuing anti-land-acquisition protests (see figure 3 ). The counter-protestors also came from small landholder families and many of them had also willingly given up land in lieu of compensation from the government. In certain cases two brothers in same family will have radically different opinion regarding land acquisition and the factory. The ones who supported the project did not think of organizing because they thought they are in favor of the government and there was no need organize and campaign separately as the government has always been doing so.

The third paradox was that a regime known for its acumen for populist electoral politics goes against its electoral base in the villages. Many academic commentators on the Marxist regime have attributed the Marxist regime's electoral and political success for last 30 years to a particular intuition of keeping various rural groups, such as the small landholders and landless laborers, on board (Bhattacharya, 1999 ; Rogally, Harris-White, \& Bose, 1999). While the regime favored the small landholders by distributing agricultural land among small landholders of middle castes, Mahisyas and Goalas, the landless were co-opted by ostensibly raising the issues of wages with their employers i.e. small landholders (Bhattacharya 1999). Why would a regime known for a sharp understanding of electoral politics and balance of power jeopardize its support base by forcibly acquiring land from the small landholders?

The fourth paradox was that even though ultra-left parties and activists, ${ }^{5}$ such as the various ultra-Leftist Marxist-Leninist groups, civil society organizations and Leftist intellectuals and activists participated in a vociferous campaign against the ruling Marxists,

\footnotetext{
${ }^{5}$ By ultra-left parties, I mean Communist Party of India (Marxist-Leninist-Liberation), Communist Party of India (Marxist Leninist-New Democracy) and also the Socialist Unity Center of India or SUCI. These parties participate in the democratic structure of India but remain marginal. I do not refer to the Maoists because the Maoists are not active in the agriculturally fertile parts of West Bengal that I am looking at in this paper.
} 
The Nano Controversy: Peasant Identities, the Land Question and Neoliberal INDUSTRIALIZATION IN MARXIST WEST BENGAL, INDIA

the popular appeal of these ultra-leftists and the post-developmentalist activists ${ }^{6}$ and their agenda remain marginal in the agriculturally fertile parts of West Bengal, such as Singur. The anti-land acquisition protests, which were seen by the ultra-left as a spontaneous resistance to neoliberal policies of the central government consolidated the position of the Trinamul Congress in the province, a stronger ally of the neoliberal regimes at the center. ${ }^{7}$

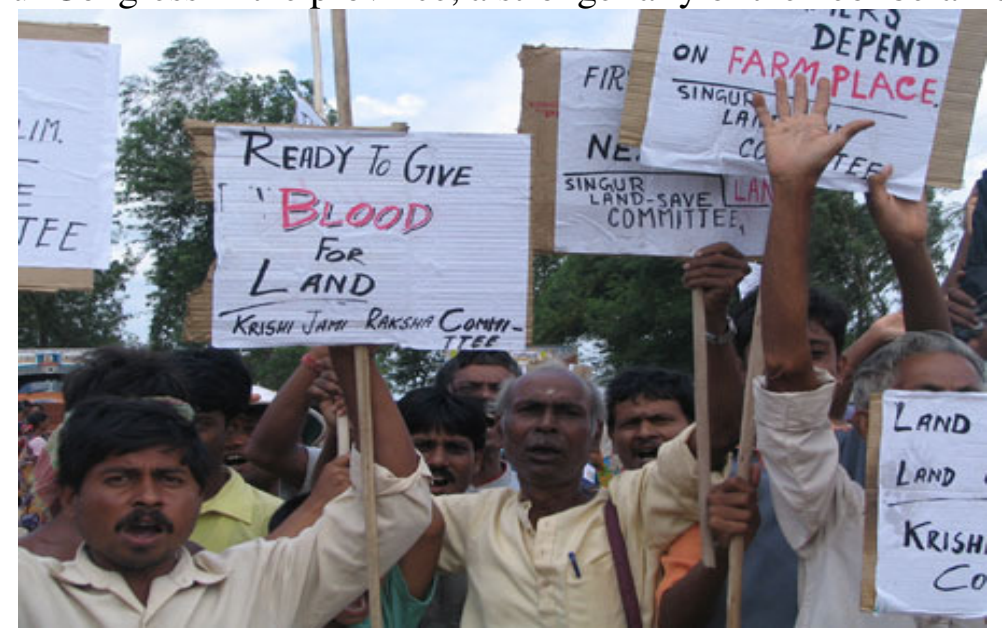

Figure 1: Protests against Land Acquisition, Singur October 2006. Photograph by author

\footnotetext{
${ }^{6}$ The activists who think that the ideas of modernization and development are ideologies of elite domination of the society. Therefore, it is futile to argue for a just development or modernization process rather one must oppose modernization and development in whichever form it appears.

${ }^{7}$ While the ruling Marxists have also supported the liberalizing Congress regime at the center but they did not take cabinet positions. The Trinamul Congress took cabinet positions in both Bharatiya Janata Party led government and in the Congress government.
} 
The Nano Controversy: Peasant Identities, the Land Question and Neoliberal INDUSTRIALIZATION IN MARXIST WEST BENGAL, INDIA

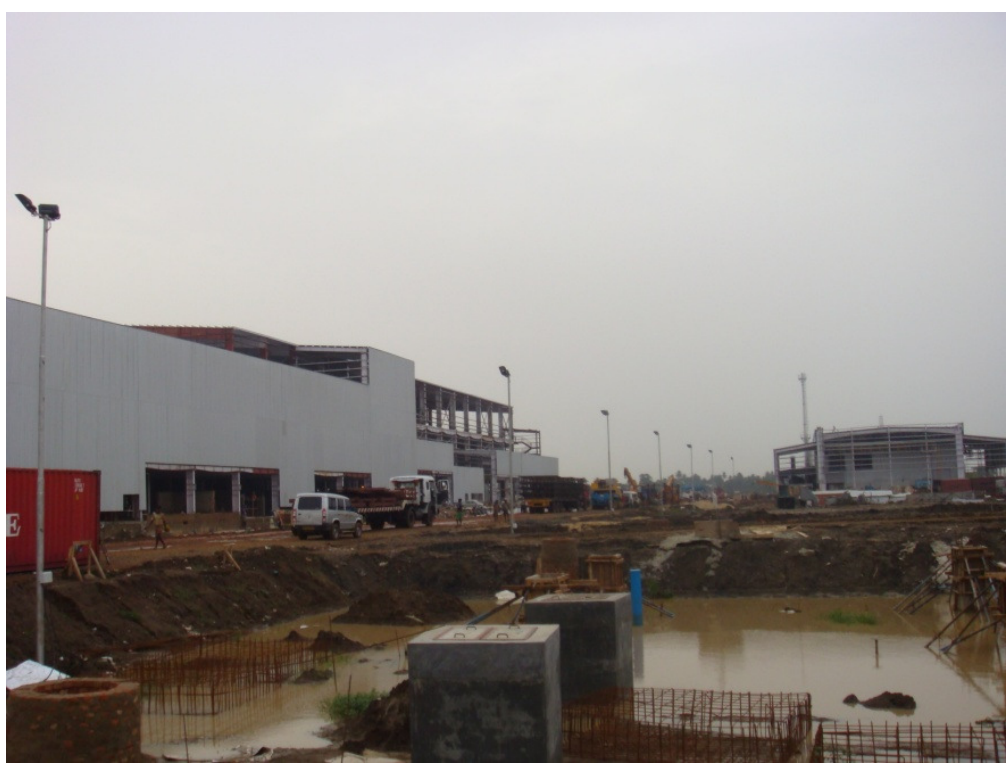

Figure 2: Factory was built on the acquired land in August 2008. Photograph by author
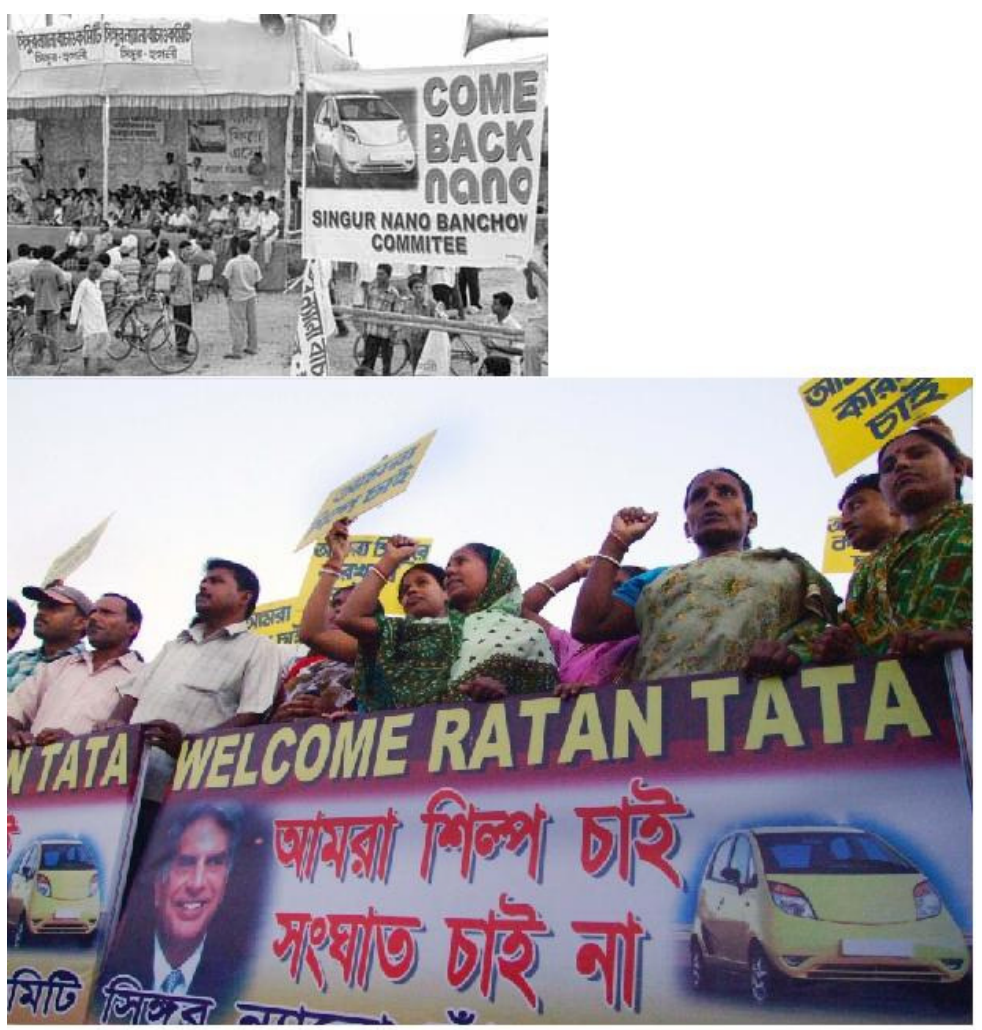

Figure 3: Counter-protests to bring back the factory after Tata Motors pulled out in November 2008 
The paradoxes raise doubts about the public image of the protests that has been portrayed by activists and ultra-leftists as simply anti-globalization and anti-industrial. To call these protests anti-globalization or anti-industrial is to assume certain simple and clear-cut intentions behind the actions of protestors, which are in reality much more complex. As I have said the counter-protesters were also villagers of the same or similar social standing as the protesters. The fact that neighbors and brothers had different and diametrically opposed viewpoints regarding the project shows that the protests are only a part of a much more complex reality, which cannot be discerned through a unified voice of the "peasants." The unified voice of the "peasant" as constructed by the activists and urban intellectuals not only subtly suppresses multiple opinions and voices in the village regarding the project, it also hides contradictions within individuals who protested and this is why issues of selfunderstanding and subjectivity of the villagers and meanings of land become salient.

In rest of the paper, I will first theoretically reflect on the issues of land and social distinctions in the villages, capitalist globalization, state ideologies and administrative and bureaucratic practices of the state (or governmentality). Second, I locate West Bengal within the political geography of investments in post-liberalization India. Third, I show how land-based practices of government and self-understanding in the villages were used by the Marxist regime to rule the West Bengali countryside, and finally, I explore the meanings of land generated at interstices of governmental techniques and discourses of improvement to address the paradoxes.

\section{Reflecting on Theoretical Frameworks through the Paradoxes}

To address these paradoxes, I suggest a broadening of the theoretical perspectives on the relationships between state ideology, capitalist industrialization and the actual rule and bureaucratic practices of the state (or governmentality). First, we need to look at the relationship between state, capitalist industrialization and governmentality. In order to do this I will draw on anthropologist Aihwa Ong (2006). Second, we need to revisit the relationships between land, subjectivity or self-understanding, rule of the regime or the state and discourses of improvement. In short, we need to understand what land means to a small landholding villager, who occupies a particular social position in the village social landscape.

\section{State and Capitalist Industrialization}

A socialist regime undertaking capitalist industrialization is also the puzzle that bothers Aihwa Ong. But unlike David Harvey (2007) who sees the state as an unitary actor, which 
has certain ideological position, Ong (2006, p.12) asks us to look beyond the ideological views of the state or the regime and focus on practices of the states and the regimes. Ong does not see the states as unitary actors with certain ideological moorings. Rather Ong focuses on the logic of practices of government or political practices of the state. Similarly, neoliberalism can also be seen in terms of practices of government or the logic that they embody. If neoliberalism is viewed in terms of political practices one can understand the mobility of neoliberal technologies and their adoption by various kinds of regimes. These neoliberal practices, Ong argues, typically tend to favor big and corporate capitalists or often the talented and educated professional or managerial class at the expense of the ordinary citizens. Frequently, rights of the ordinary citizens are curbed to give incentives to corporations and its managers. But all this is done in the name of developing a national economy, which is understood to be one step further towards a nationalist or ideological goals of achieving a utopian nationalist or socialist future. By doing this the neoliberal political practices run counter to or stand out as exceptions to the dominant democratic or populist practices based on a territorial logic which entitles citizens to resources and privileges simply by virtue of being born or being a resident within a particular territory. Neoliberal practices operate by separating the national economy, which is given more importance, from the national "anthropos" or people, which is given less value or weight in the political practices of the state (Ong, 2006 p. 32). Special Economic Zones which undermine the existing labor laws of a country or enjoy subsidies on key industrial inputs epitomize the strategies of what Ong calls making "exceptions."

Ong's (2006) analytic of exception is an apt characterization of the Marxist regime's very recent actions to please private investors, especially the application of the eminent domain act to acquire land. Also, the deployment of the police force against the same small landholding villagers who saw police acting in their favor to acquire land from the big landlords thirty years ago stand out as an exception. "This government gave us land but why are they taking that away,"8 wondered many protesting villagers, whom I interviewed, unwilling to accept compensation for their plots. Moreover, the general pro-industrial rhetoric of the provincial government valorized entrepreneurs and engineers and the medhabi or talented individuals. Thus, there was an attempt to make exceptions to the usual populist political rhetoric and practices of the Marxist regime in West Bengal that idealized peasant and vilified the big capitalists.

However, rather than identifying a logic in the regime's or the state's strategies and practices that seem to underlie the actions of many regimes, which are either left-of-the center or which are ideologically opposed to liberalism, such as the ones in China, Vietnam, or Malaysia, Ong's framework does not take us very far in answering the first paradox:

${ }^{8}$ Interviews done in Bajemelia in Singur in October 2006. 
Why did the Marxist regime adopt a neoliberal industrial policy that favors big corporations. Was it simply the whims of the party bosses wanting to make money? Was it simply an elitist urge? Or was it external pressures of the global market and central government? It cannot be simply the whims of the party bosses, who know that they have to get re-elected every five years unlike the regimes in China, Malayasia or Vietnam. Middleclass Bengali Bhadralok ${ }^{9}$ elite's urge to see their province industrialize can be a possible reason but as I have already mentioned the support-base of the Marxist regime lay in the villages. So, pleasing and urban elite middle-class population may not have motivated the Marxist regime.

The external pressures of a global capitalist economy, however, are an important factor. Scholars have focused their analyses on global capitalism as an impersonal force characterized by an international division of labor, flexible production controlled by transnational corporations, revolutions in communications and other technologies that is transforming local cultural practices and reshaping our perceptions of space and time. While I agree with this explanation largely, the problem with the "capitalism-as-animpersonal-force" explanation is that it privileges impersonal force of capital as the sole organizing principle of analysis without looking at the desires and aspirations of actual people on the ground whose cultural orientations have been formed by ruling practices or strategies of the state or the regime for last thirty years, which subtly privileged certain groups over others to win elections and to maintain a steady support-base. Thus, I draw on Ong to focus on the administrative and ruling practices of the state but I go a little further to focus on how those ruling practices have shaped personalities and self-understandings of small landholding villagers. In the case of West Bengal, ownership land features as an important component in this strategy of rule of the Marxist government and the selfunderstanding of the villagers to which I turn next.

\section{Land, State and Governmentality}

The issue of land and capitalist expansion has been understood by Marxists of various shades in terms of how land, a necessary factor of production, is appropriated by capitalists to maximize profit and therefore expand and reproduce the hegemony of large capitalists (see Harvey 2007). In this framework, the relationship between land and the people who are dispossessed of it is seen to be one of collective or individual ownership of, access or entitlement to a resource that gives sustainable livelihood, security, and protection from the market forces.

\footnotetext{
${ }^{9}$ Literally meaning "gentle folk" but it also refers to an urbanized elite and educated group who are mostly salaried employees of the state or the private sector.
} 
While the above formulation is partly accurate, relationship of individuals and groups to land can also be seen in terms of how ownership of land shapes village social relations, and the subjectivities and self-understandings of the landowning families. Ownership and (non)ownership of land form the matrix of social relationships and distinctions, within which villagers imagine their life trajectories. Typically, a small landholder's son, who received school education, will look down upon engaging in agricultural work. His father or mother may not have farmed the fields themselves but have simply supervised the farm laborers, who are landless villagers. His grandfather probably tilled the land till he came to own a small plot of land as an outcome of the Marxist government's land redistribution policy. Thus landownership is an important social marker, which differentiates the orientation and outlook of the small landowning families from the landless families. Therefore, landownership is also a basis for social power, desire, lifestyles and local and regional trajectories of upward mobility, which both facilitates and contests hegemonic processes and policies that favor large capitalists.

From this perspective, land is not simply a plot to produce food-crops but it is also a positional good that shapes a social field of relations based on distinctions and selfunderstandings, which stratifies a locality, village or community. The regime in power or the postcolonial state uses such self-understandings to establish a particular kind of landbased governmentality or ruling practices, which help the central authority (and in the case of West Bengal, the Marxist party's authority) to penetrate rural society, exact compliance, and invoke commitment and expectations based on a discourse of improvement, development and progress (Sivaramakrishnan, 2000). It is important to look at the land question in West Bengal and elsewhere from the perspective of land as shaper of a social and political field that generates desires and expectations for social mobility and demand for non-farm employment.

The land-based governmentality or rule of the Marxist government relies on certain moral and informal claims and expectations that small landholders have on the state. The claims and expectation include subsidies on agricultural inputs, quelling the demands for increasing wages from the absolutely landless, and also protection from the erstwhile landlords whose land was redistributed by the Marxist government. These claims are deeply intertwined with the efforts of the small landholding families to maintain their social positions within the village. Thus by redistributing land the Marxist government has created a support base, which remains dependent on it. This latter technique of rule and getting reelected in the elections through mutual dependency between a rural small-landholding group and the regime is what I call "land-based governmentality."

However, the claims and expectation on which the land-based governmentality operates have been changing because of decreasing agricultural productivity due to dwindling sizes 
of plots and, which get subdivided in every generation. Also, new expectations and claims on the state are arising because land redistribution has brought modicum prosperity to the small landholder families. Thus new expectations and claims no longer entail only land redistribution and agricultural subsidies but also demand for non-farm employment. The old and the new claims and expectations from the state-or older agricultural priorities and newer priorities that emphasize non-farm employment-taken together is a source of contradiction for the newly emerging rural subjectivity or self-understanding in agriculturally fertile parts of rural south West Bengal. This newly emerging subjectivity can neither be any longer co-opted within what I have called a land-based governmentality of the Marxist regime, which form the context of new demands and aspirations, nor within neoliberal discourses of industrialization, which undermines citizenship and democratic rights. This results in state repression and violence as has been perpetrated by the Marxist regime in West Bengal, recently. However, the rural subjectivities are also not adequately represented in the ultra-left and activist discourses that describe small landholders as pure and poor peasants dependent on land simply for food security.

Possession of land is the core of the newly emerging subjective identity which desires development, urban and non-farm employment and seeks to straddle the multiple and political worlds of difference. However, industries, development and urbanization also require land. This is the basic contradiction that pervades the subjectivities of the villagers. The policies of the regime are a response to that and so are the protests and counter protests. Yet the state-sponsored neoliberal discourse of industrialization cannot integrate this contradictory core of rural subjectivities, which have emerged as an effect of the Marxist state's governmentality practices that promoted individualized landholding over collectivized agricultural landholdings, production and marketing of agricultural crops (Harris-White, 2008). Hence, the post-developmentalist and activist ultra-left narratives about peasants and resistances also fail to integrate the newly emerging self-understandings of the villagers who are not only peasants but have numerous other occupations, such as jewelry work, petty trade and government service (see table 1). Thus, the peasant, which refers to a heterogeneous group of small landholders resist symbolic integration into opposing narratives of projected future of the Marxist-led neoliberal and developmentalist state and the activist and non-institutionalized or the ultra-left much like the "people" of Ernesto Laclau's (2005, p.152) On Populist Reason. Populist figures and parties, such as Mamata Bannerjee and her party Trinamul Congress perfectly represent the popular subaltern subject because neither she nor her party has any specific ideological agenda. Mamata Bannerjee's subaltern demeanor and her out-of-the-place presence in altars of high politics such as the state assembly and the Indian Parliament, which are usually laughed and mocked at is precisely the excess, which sanitized world of Westernized urban middle class politics cannot tolerate. Nonetheless, this populist excess, which refuses to be co-opted is both the strength and weakness of a populist critique of neoliberal industrialization. 
Next, I discuss the political geography of investments in India, which will help us understand and appreciate the tension between the West Bengal's Marxist regime and newly emerging expectations for non-farm employment of the small landholding individuals.

\section{Geography of Disconnect}

To appreciate tension between the older expectations and new demands and expectations I am going to briefly comment on the industrial situation of West Bengal. It is important to look at the political geography of private investments in manufacturing industries across the Eastern and Western regions of India. The political geography is a composite effect of central government policies (Chakravarty and Lall, 2007) and relations between the central government and the provinces (Sinha, 2005). One self-sustaining outcome of this geography has been a masking out of certain regions from the heads of private investors. The Freight equalization Policy of 1956 equalized the prices for essential items such as coal, steel, and cement nationwide. This effectively negated the location based advantages of regions that were rich in these resources and placed them at a disadvantage relative to regions that produced non-essential items whose prices were not equalized. The affected areas were southern Bihar, western Orissa and eastern Madhya Pradesh and also West Bengal (see Chakravarty and Lall, 2007: 207). The Freight Equalization policy has been discontinued since the early 1990s, but the damage may already have been done. In postliberalization period when private investment became the key to industrialization, West Bengal lagged behind in attracting investments because of the "investor-unfriendly" attitude of the West Bengal government, which led to an inability to deliver incentives, such as cheap land and other infrastructures to private investors on time (see Sinha, 2005:225).

Thus lesser industrialization of West Bengal is a typical case where a possibility of a virtual systematic expulsion from capitalism is in operation (see Map 1). Postliberalization investment and reform outcomes clearly suggest that the virtual landscape of money and investment flows, finance-scapes (Appadurai, 1996), come into being not simply through inclusion but also through exclusion. Decision-making of capitalist investors create differentiated spaces where some places are site of sourcing raw materials and labor and others are centers of concentration of investments in infrastructures, technology and manufacturing industries (Smith, 1998). This unevenness is not an aberration of economic development within capitalism but it constitutes capitalist globalization as Manuel Castells (2000) points out. However, in the case of West Bengal Leftist trade-unionism and Central government policies worked together produce the economic geographic unevenness that we see today. 


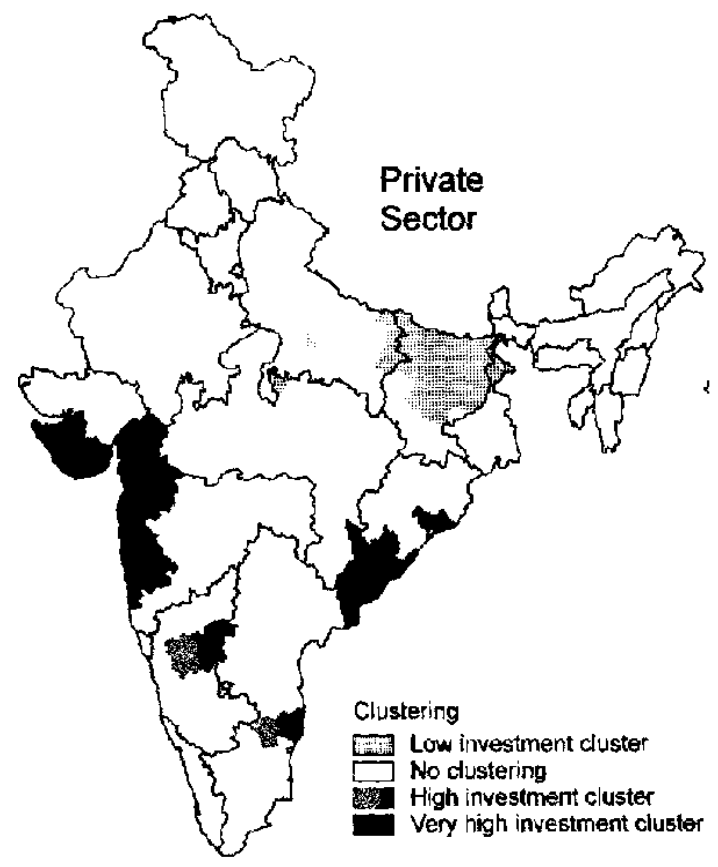

\section{Map 1: Clustering of private investments in India in the Post-Liberalization (1990) period. Source: Center for Monitoring Indian Economy (CMIE)}

The subjective experience of such spatial division and unevenness has been most tellingly expressed by anthropologist James Ferguson (2002) in terms of the word "disconnect" (141). The West Bengal province has seen its industries decline so much in the post independence years that the specter of this "disconnect" is part of the lived reality of the people in rural and urban areas alike and results in massive migration of people. In response to my interviews many older villagers would say that in their time jobs or work were readily available in their district but now youngsters have to leave their families to go to other provinces. A short survey among 70 small landholding families and informal conversations with many villagers revealed that at least one young member from each of the small landholding households stays and works in cities such as Mumbai, Delhi, Ahmedabad or Dubai as jewelers. This absence is the concrete result of such a "disconnect." Moreover the village youngsters working in jewelry sector who occasionally return to their villages 
consider the nearest city of Kolkata as "second-class" city when it comes to wages for their work because "enough money does not roll here.",

\section{Land-based practices of government and self-understanding}

The Marxist government's land redistribution has been very selective and motivated by clever electoral calculations. Although 80 percent of the land in West Bengal and in Singur lies with the small and marginal landholders (see figure 1), the Marxist rule in West Bengal and its decentralization project have not devolved power to the poorest in the villages (Bhattacharya, 1999, (Webster, 1999)). The small landholders, who are both numerically predominant and also own substantial land among themselves, are the ones who collectively enjoy the most power in the rural areas. While an older colonial absentee landlordism of Brahman and Kayastha family is gone, the new big men in West Bengali villages are the small landholders, who belong to Mahisya and Goala castes (Rogally, Harris-White, \& Bose, 1999). The middle-castes, Mahisya and Goalas, who had spearheaded the movement against land acquisition in Singur, were the main beneficiaries of land redistribution, implementation of sharecropping rights and improvements in agriculture. In Singur as in rest of West Bengal, there was relatively little agitation on issues of agricultural workers or laborers (see Bhattacharya 1999). The wage of the day laborers vary everyday and most of the laborers are not aware of the state minimum wage i.e. Rs. 67.50 (\$1.48).

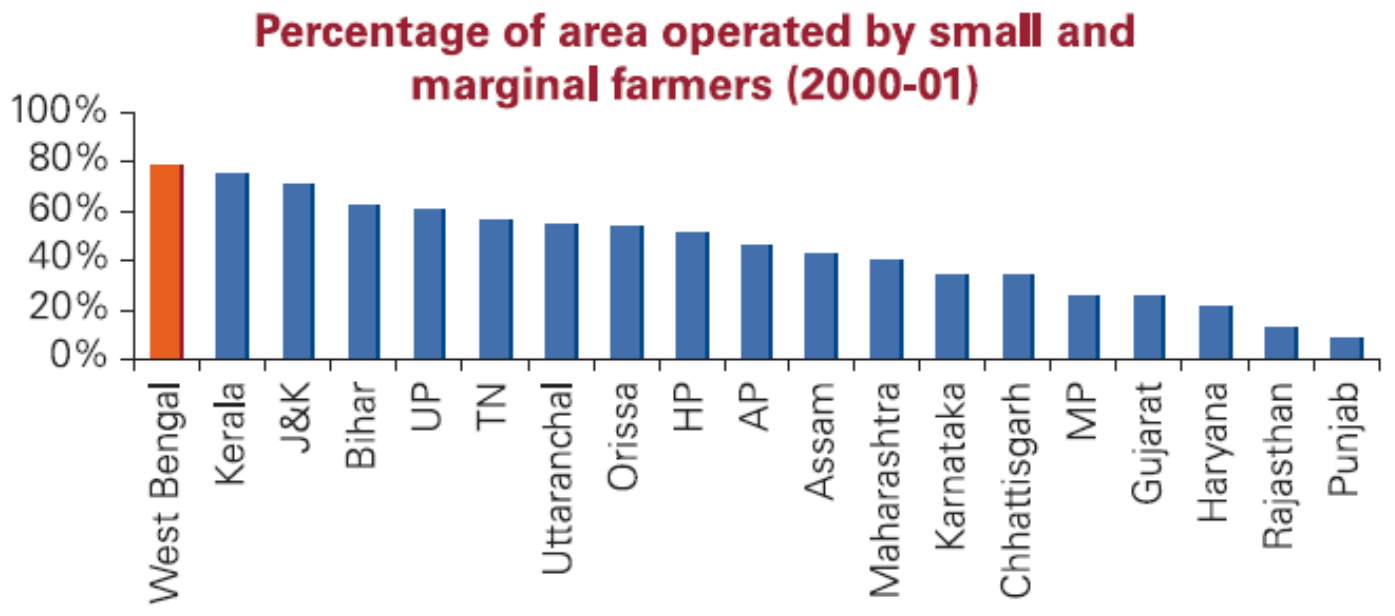

${ }^{10}$ Interview with villagers in Sahanapara, Singur block, Hooghly district, personal fieldnotes $12^{\text {th }}$ October, 2006. 
Figure 4: Percentage of area operated by small and marginal farmers in different Indian provinces (2001) Source: KPMG-CII Report on West Bengal, December, 2007.

Table I: Percentage of distribution of population according to different categories of workers and non-workers in the Singur block, Hooghly District, West Bengal $2001^{11}$

\begin{tabular}{|l|l|l|}
\hline Types of Workers & Number of Workers & Percentage to total worker \\
\hline Cultivators & 14,973 & 15.9 \\
\hline Agricultural laborers & 15,584 & 16.6 \\
\hline Household Industry Workers & 8,788 & 9.4 \\
\hline Other Workers & 54,622 & 58.1 \\
\hline
\end{tabular}

Source: Census of India, 2001

Likewise, the land of the small landholders was also less targeted for land redistribution (Bardhan \& Mookherjee, 2000). The small landholders who themselves benefited from the laws against eviction vis-à-vis the older landlords would not let the landless who work in their fields to register themselves as sharecroppers. Thus the tilling and labor-intensive tasks are mostly done by day laborers, who were local or migrant low caste or indigenous landless men or women with little or no access to land. This class difference within the villages is the result of an implicit and non-juridical understanding between the state and the small landholders. This understanding underlies what I call the land-based governmentality of the Marxist regime.

This implicit understanding can also be illustrated by the way government kept the record of the changing character of cultivated land. The acquisition of 1000 acres of land had taken away plots from 12,000 small landholders and access to land from 3000 registered sharecroppers. In exchange, initially the landowners were offered cash compensation which is a little above the market rate for the plots. The government had claimed that according to its records the 1000-acre stretch is single-crop marshy land. Thirty years ago the stretch was mostly marshy. Green revolution and improvements in irrigation, especially introduction of electric pumps to exploit ground water, have changed the agricultural profile of certain parts of the area in last 30 years. Many small land-holding farmers, however, prevented updating of records because fertile agricultural land requires them to pay more taxes. My interviews

${ }^{11}$ According Dipankar Gupta (2008) dependence on agriculture for work is over-reported in the Indian census. 
with land bureaucrats and senior villagers revealed that lower level bureaucrats who were responsible for reporting changes in the agricultural profile would just listen to what the small landholding villagers tell them about their fields.

However, this implicit understanding notwithstanding the small landholders, who are more or less a rentier group, are impoverished and poor because of their dwindling land sizes and limited access to markets. Yet their cultural practices and aspirations are different from the agricultural workers over whom they boss.

The Marxist regimes land-based techniques of government were accompanied by important changes in cultural practices of small landholding groups in villages. Land redistribution and green revolution and a modicum rise in agricultural production have led to a mutation in the identities of the small landholders, who call themselves chasi (cultivator, peasant) vis-à-vis the majurs or laborers or agricultural workers. As a result of vast increase in village primary schools after independence, many elements of urban lifestyles, such as literacy pursuits and political leftism, blended with the peasant/cultivator ways of living. Literacy in the extended sense of knowledge of poetry, drama and Tagore songs became a fundamental ingredient in peasant/cultivator lifestyle (see Ruud, 1999). Being educated and cultured have a double meaning. It means cultivating an ethic of non-manual or at least nonagricultural work but it also means a certain fetishization of peasant ways of life, thanks to leftist poems in the school text books. Here, I will quote from a poem by Dinesh Dash that is found in all Bangla school textbooks published by the government and read by students from small landholding families. I also knew this poem by heart when I was in school and found activists reciting the poem in protest meetings. The title of the poem is The Sickle:

Sharpen your sickle, my friend

Perhaps, you loved the crescent of the new moon very much.

But this not the age of the moon,

The moon of this era is the sickle.

Older villagers in my fieldsite would regularly complain that the day they taught their children to wear slippers and shoes, they would not go the field. Now, they do not even know where the borders of our plots begin. Also I would see change in the difference between sartorial choices of the older and middle-aged and young villagers belonging to small landholding castes. Older individuals were clad in dhoti or lungi; the younger and 
middle-aged ones would wear shirts, trousers, and occasionally slippers or shoes. This change in the self-understanding has generated what Marc Edelman (2005) calls new and contemporary rural moral economy. Thus claims of the villagers on or against the government or the state go beyond simple agricultural issues or subsidies. To put in the words of one of my respondents: "If Tatas can build so many factories, why cannot I buy two motorbikes? But simple agricultural income is not enough for that." 12

The middle caste small landholders who think of themselves as moddhobitya or middleclass, hardworking and teetotalers understand themselves in opposition to the landless agricultural workers, who they think are lazy, drunkards who can neither control nor govern themselves nor their animals, such as goats which come and eat crops in the fields of the small landholders.

A section of these Mahisyas and Goalas and small landholding villagers have emerged as small and medium entrepreneurs. The small and medium businesses include brick kilns, jewelry workshops, construction work and local and long distance transport companies, and rice mills. The primary source of capital for these medium entrepreneurs is the cash earned in the service, jewelry or in construction sectors and cash is also earned through by speculating on land. While agricultural Mahisyas and Goalas, who benefited from land reforms and enjoy agricultural subsidies forms a traditional base of the Marxist party and youngsters and the newly emerging entrepreneurs tend to side mostly with the main opposition party Trinamul Congress, which is actually an ally of the liberalizing parties at the central scale. Thus Marxist regime faces an uncomfortable challenge from the new rural small and medium entrepreneurs and the young men who would like to work in the nonagricultural sector because they cannot be contained or won over by the usual land based governmental techniques.

Ironically, the three hundred small and medium local entrepreneurs who supplied labor and materials to the Tata factory in Singur were mostly supporters of the main opposition party Trinamul Congress.

To explore the tensions arising out of economic relationships around land, I will present small vignettes.

\section{Liakat Mallik}

${ }^{12}$ Interview conducted on $17^{\text {th }}$ November at Gopalnagar, Singur, Hooghly West Bengal 
Liakat Mallik of Joymollah village was a landless laborer who had been farming the land of the Goala Ghosh's for last five or six years. I came to know about Liakat through his wife whom I met while interviewing agitated villagers in Dobandhi and Joymollah neighborhoods. The landless laborers were both tense and flustered because they stood to loose access to the land which they had been cultivating for last five or six years. While the registered sharecroppers were offered $25 \%$ of the value of the plot which they farmed, the government had not announced any compensation for the unregistered sharecroppers. ${ }^{13}$ The middle caste- Mahisya and Goala landowners will not let the landless laborers register as sharecroppers. As I talked to Chitta Moitri, Putul Mali, Dilip, and two other women, they complained that for last fourteen years the sharecropper registration has been stopped. The registration process is a two-step one. First, the landless laborer goes to the Block Development office or to a local branch of the office and applies for registration. Second, the inspector comes to verify if the laborer actually cultivates the plot that he claims he cultivates. Inspectors ask the landless laborers working in the neighboring plots to attest if the landless person in question cultivates the plot or not. However, as most of the plots are owned by Goala and Mahisya families, the landless laborers could attest only at the risk of eviction or spoiling their relationship with the group small landowners. A woman who conspicuously had her head covered by her saree started grumbling about the small landowners. On further questioning, she asked me to talk to her husband Liakat.

Hearing that the government was taking away the land and compensating the small landowners and registered sharecroppers, Liakat had gone to register his name as a sharecropper. But the day the inspector came, Liakat went to the market area for some work. The small landowners Jamini Ghosh, a Goala and his relatives stopped him at the marketplace and beat him up and asked him sign a document saying that he does not work in their land. Incidentally, Jamini Ghosh and his sons were supporting and actively participating in the movement against land acquisition.

\section{Kalyan}

I met with Kalyan, a Mahisya young man at a tea-shop. Kalyan used come to chat with other youngsters of his age. In the friendly debates with his village mates Kalyan would vociferously argue against acquisition of land. He would say "our land is the factory for manufacturing food. We will manufacture food and in the era of globalization we can buy motorcars from others." Kalyan's father and his uncles have more than 20 bighas of land. Kalyan's brother is studying veterinary medicine. Kalyan's father who used work with the Indian railways has bought Kalyan a motor tiller but still Kalyan has been trying hard for a

13 Some of them were compensated later. 
government service. He has passed his Bachelor of Arts examination in history with a poor grade. He is desperately looking for a teaching job in a school. I asked him "so aren't you concentrating on agriculture?" Kalyan smiled and replied "Who will marry a farmer. These days people do not want to let their daughters marry into farmer households". Although this is not true of all village households, in Kalyan's status or caste group marrying into a farmer household is not very prestigious. Kalyan, however, added that farming is not as high-status job as it is Punjab, Haryana, or Uttar Pradesh. I asked Kalyan if you get a job in government or the private sector, are you going to loose your interest in land. Kalyan replied "No, then I will be the proprietor.",

\section{Mahadeb}

Mahadeb Khanra, a Mahisya small landholder mobilized public opinion against the government and also contacted the office of a transnational NGO fighting for food security and sovereignty. Mahadeb and his brothers also had approximately 12 bighas of land, part of which was facing the highway. One of Mahadeb's brothers worked in a government concern in the nearby town. Mahadeb also used to work as a jeweler in Western India. He had planned to buy more plots along the highway with the money that he had saved. $\mathrm{He}$ thought of building shops, hotels or restaurants. But the acquisition had jeopardized his dreams. Mahadeb expressed his grievance by saying "I thought of becoming an industrialist but ended up as an activist."

\section{At the Macha}

The best place to talk to small landholding farmers was under the macha, a sitting and resting place made of bamboo and hay. The usual routine of the small landholders was to go to the field early in the morning to hire migrant laborers, give directions about work, and come back to the village and take rest under the shade. The land acquisition and associated politics dominated the discussion. The main concern for the male farmers was that the value of the land that they are being forced to give up will appreciate more in next ten or twenty years. Why would they give up land now? They had to pay dowry for their daughters who will be married away. Moreover the government is paying the compensation money according to the Hindu inheritance law that pays equal amounts to the brothers and sisters. They would say sisters have left with the dowry, now why would they share the money with the sisters. They would say theirs is a "sona" land and the government could have taken the rupo (silver) referring to the land in other villages. Less fertile land were mostly used for

${ }^{14}$ Personal interview October 2006. 
grazing goats by the members of castes of landless laborers. The government was criticized less because of zealous attitude to bring investments but more for its past mistakes in encouraging trade union movements in the industries. Some would say that the left government would shut the factory down.

While land controversy raged in Singur, workers at a nearby Hindmotor automobile factory struck and demanded more wage and bonus. But the small farmers were not sympathetic to trade union politics. Many of them would sympathise with the factory management and would say that the factory workers were not skilled enough. They would give the example of the laborers who work for them. The productivity in their fields decline, they would argue, because laborers or majurs were not skilled. Thus landownership and ability to employ majurs made the small landholding individuals empathetic to capitalist views although their protests were against acquisition of land for a private investor.

\section{Balai Sahana}

Balai Sahana, Mahisya landholder, owned 5 bighas of land, about 200 yards from the highway. Two or three years ago he heard that a gas station would be constructed and many small landholders had sold land to a local entrepreneur. He realised that the gas station could block the passage of water from his plot. Thus he understood he would not be able to drain out the water if there was heavy shower. He went to everybody in the village to ask if the construction of the pump can be stopped. As the opposition party members ran village panchayat or local government, he specifically went to them to request if any thing could be done to the problem. But his concerns fell to deaf ears. The gas station came up and his plot would be submerged during heavy shower. He cursed the opposition party members and said "that they did not pay any heed to my problems, now they are destined to suffer." Balai had also joined the labor force along with another 700 landless laborers or small landholding farmers who are helping the government set up the factory.

\section{The Jewelry Workers and "Rolling of Money"}

Many young men from the small landholding households migrate to Jaipur, Ahmedabad, Bombay, Delhi and Madras and even to Dubai to work at jewelry workshops. Out 70 households that I interviewed during my field work period in different villages, I found every household has at least one young male member staying in other provinces or abroad. Shiben Shi, a local youth in Gopalnagar village also works as an insurance agent to this diaspora. Most of the year he travels between various Indian cities to serve his dispersed clientele. Few of the young men who migrate settle down at the places where they work. They usually return to their villages to settle down and invest their money in other businesses or they set up jewelry workshops. I met a couple of them who were 
visiting their family temporarily. Clad in trousers, shirts and expensive slippers or shoes, the three young men chatted when I ordered for a cup of tea in a tea-shop. Other villagers addressed them enthusiastically and asked them about when they came home. I asked them about their work and why and where did they migrate. Agriculture, they said do not allow them to make enough money. Jewelry, for them, is a skill, which give them more opportunities for earning cash. They said that it is difficult to find well-paying jewelry work in Calcutta because "not enough money rolls here" (there is not many persons to afford expensive jewelry that his company abroad makes).

\section{A poster}

Most of the posters or wall graffiti against acquisition were put up at places frequented by villagers, such as on the walls of buildings facing the main road that goes inside the village or the tea shop. These posters or wall graffiti would appeal on behalf of the "village" or "peasants" or "farmers". Parties that would put up the posters or write the graffiti would also put their names in them. However, I also encountered a strange poster in one of the village by-lanes. The poster was not under the sign of any known political outfit. It did not appeal on the behalf of "peasants". The message in this small poster was an appeal to the particular caste of Mahisyas. It referred to and denounced the enthusiasm among the young Mahisyas who were reveling at news of a factory being set at their locality. The poster read like this: "The Tata factory that is coming up in Singur will actually "produce" (read: bring in) refugees (bangal). The educated local Mahisya boys, who are enthusiastic about the development, will not get anything out of it." The poster reflects an influx of outsiders coming in and vitiating the village life. The poster, interestingly, was not addressed to the government, but to the villagers who were in favor of the factory.

The exploration of the social field shows that the character of the land as a resource creates hierarchies even after redistribution. While redistribution of land democratised the access to land, it also created a landed group that lives off the land. The individuals belonging to this group have twofold anxieties. They fear the fragmentation of land and loosing land to the government projects. The former is addressed by a constant search for non-farm employment which the manufacturing sector or the service cannot generate. The latter is addressed through an appeal to the urban activists whose anti-capitalist ideological and political views, the middle peasants only partially share. The poster reflected a contradiction within the subjectivities of the villagers, which had also divided the village into pro-project and anti-project groups cutting across caste and party-lines. 


\section{Conclusion/Emergent Meanings of Land}

Land, thus, is not just a plot for cultivation and self consumption of crops nor is it simply a plot to grow crops for sale in the market. These are the two usual poles along which a "peasant" is distinguished from a "farmer." In order to understand the protest against land acquisition, I propose, following Michael Kearney (1996, p. 161) one has to go beyond this usual binary understanding of land based on the use value vs. the exchange value.

Land is a marker of prestige, influence and security. Money earned by selling land also serves as dowry for the daughter. Land gives one the ability to employ or boss over the landless laborer. Land is an object of dispute between brothers and sisters, neighbors and families and also local members of the political party. The speculative value of land dependent on industrialization and urbanization also plays a part in rural social relationships. In short, possession of land is the core of the subjective identity which desires development, urban and non-farm employment and seeks to straddle the multiple and political worlds of difference. However, industries, development and urbanization also require land. This is the basic contradiction that pervades the subjectivities of the villagers. The policies of the regime are a response to that and so are the protests and counter protests. The exceptional framework of understanding, proposed by Aihwa Ong and Harvey's "accumulation by dispossession" formulation, are powerful frameworks but in order to fully understand the paradoxes one has to attend to the complex identities and contradictions in subjectivities formed around ownership of land and within the dominant governmental techniques of the regimes.

Government of a population not only entails classification of population into groups and categories. Following Paul Veyne, Graham Burchell (1991) points out that there is a problem of subjectivity in politics (119). Therefore, government or rule of the regime or the state also requires creating subjectivities, desires and differences within the population that have its excesses and contradictions. Aiding and abetting capitalist industrialization and serving the interests of big capitalists are responses of a post-colonial Marxist regime, which is unable to manage the differences, desires, expectations that it has fostered to sustain a consensus among various sectors of the population and maintain its hegemony and electoral successes without challenging the colonial and modernist underpinnings of its ruling practices. Here, it seems, also lay the key to understand many other ideologically socialist regimes, which has adopted neoliberal policies.

However, urban activist and non-institutionalized leftists saw the protests as an antithesis of global capitalism and the protestors as idealized peasants concerned simply with use-value of land. Urban activist rhetoric was replete with romanticized views about villages as bounded communities. They did not see the distinctions within the villagers nor their changing subjectivities. The representations hinged on the view that any compensation and rehabilitation for the land losers will be incommensurable because loss of livelihood and 
land cannot be compensated. I will just give two examples. Refer to the following: "For the people of Singur, their land is their life and part of their culture. It is a place for learning and worship" (Lahiri \& Ghosh, 2007) and Pranab Kanti Basu (2007) wrote in Economic and Political Weekly of India referring to peasants in Singur that "the peasants had a holistic culture that directly opposed the commodity culture of globalization. The concept of land as a commodity was thoroughly alien to their culture." (1283). Basu's article was based on "activist feedbacks." Argument of incommensurability prevented the activists and opposition leaders to bargain a compensation and rehabilitation package, which could be used as a tool to negotiate with the state at other sites. The activists could not even organize the more than 700 local villagers who worked in factory site into a labor union because doing that would mean accepting the project. This resulted in a paradoxical situation. Bargaining for better price and rehabilitation came to be seen as an absolute compromise. So, the Tata Motors finally pulled out and went to western Indian state of Gujarat, leaving many local youth who found work in and around the factory high and dry and hence the counter movement.

The party that emerged powerful from the movement in Singur was not the activist left outfits who indicted the ruling parliamentary leftists as unMarxists. Trinamul Congress the party of the populist leader Mamata Bannerjee emerged as the most powerful party in West Bengal and in Singur. Here lies the core lesson of the populist critique of neoliberalism and the crucial insight into the populist subjectivity, which is underemphasized in the usual Marxist narrative of class politics. While land with its familial, kinship and status associations is not a conventional commodity, the urban bhadralok activist left's representation of the peasant subject as a diametric opposite of capitalism or imperialism is also an inadequate representation of the multiplicity and diversity among the small landholders. Nonetheless the idealized figure of the peasant worked well to unite the multiple positions within the villagers but their loyalties were more towards the Trinamul Congress, which lacked the usual Bhadralok and urban respectability associated with "politics of principle" or politics of a given trajectory. Therefore, Trinamul Congress showed the promise of mediating between the multitudinous demands of the villagers and wider state and national politics. However, how much it can fulfill the promise is yet to be seen. But the activists and the ultra-left parties and social theory have lessons to be learnt from Trinamul's stunning success in managing a multiplicity of interests, views and subject-positions. 


\section{Works Cited}

Anderson, P. (2007). Jottings on the Conjuncture. New Left Review , 130-156.

Appaduri, A. (1996). Modernity at Large: Cultural Dimensions of Globalization. Minneapolis: University of Minnesota Press.

Bardhan, P., \& Mookherjee, D. (2000). emlabs Berkeley. Retrieved November 10, 2008, from http://emlab.berkeley.edu/users/webfac/bardhan

Basu, P. K. (2007). Political Economy of Land Grab. Economic and Political Weekly Vol.42 No.14, 1281-1287.

Bhattacharya, D. (1999). Politics of Middleness: The Changing Character of the Communist Party of India (Marxist) in Rural West Bengal (1977-90). In Ben Rogally et al., Sonar Bangla? Agricultural Growth and Agrarian Change in West Bengal and Bangladesh (pp. 279-302). New Delhi: Sage Publications.

Burchell, G. (1991). Peculiar Interests: Civil Society and Governing 'The System of Natural Liberty'. In G. Burchell, C. Gordon, \& P. Miller, Foucault Effect: Studies in Governmentality (pp. 119-149). Chicago: University of Chicago Press.

Castells, M. (1991) Rise of Information Society in David Held and Anthony McGrew ed. The Global Transformations Reader, Polity Press, London, 311-334.

Chakravarty, S and S. Lall. (2007). Made in India: The Economic Geography and Political Economy of Industrialization. Oxford University Press: Oxford.

Chatterjee, P. (1997). Present History of West Bengal. Delhi: Oxford University Press.

Edelman, M. (2005). Bringing Moral Economy Back in...to the Study of 21st Century Transnational Peasant Movements. American Anthropologist Vol.107, Issue 3 , 331-345.

Ferguson, J. (2002). Global Disconnect: Abjection and the Aftermath of Modernism. In J. X. Inda, \& R. Rosaldo, The Anthropology of Globalization: A Reader. Oxford: Blackwell.

Gledhill, John. (1998). "Mexican Contribution to Restructuring US Capitalism: Nafta as an instrument of Flexible Accumulation." Critique of Anthropology 18: 279-296

Gupta, D. (2008, January 25). Get Your Questions Right. Times of India .

Harris-White, B. (2008). Rural Commercial Capital, Market System and the Left Front. Oxford: Oxford University Press.

Harvey, D. (2007). A Brief History of Neoliberalism. Oxford : Oxford University Press. Harvey, David (2008). Right to the City, New Left Review 53. September-October, p. 23-40. Harvey, David (1989) From Managerialism to Entrepreneurialism: The Transformation in Urban Governance in Late Capitalism, Geografiska Annaler. Series B, Human Geography, Vol. 71, No.1, p 3-17 
Kearney, M. (1996). Reconceptualizing the Peasantry: Anthropology in Global Perspective. Oxford: West View Press.

Laclau, E. (2005). On Populist Reason. New York: Verso.

Lahiri, D., \& Ghosh, A. (2007). Our Land and their Development. People's Coalition on Food Sovereignty.

Mukhopadhyay, B. (2005). The Rumor of Globalization. Dialectical Anthropology , 29:3560 .

Ong, A. (2006). Neoliberalism as Exception: Mutations in Citizenship and Sovereignty. Durham: Duke University Press.

Rogally, B., Harris-White, B., \& Bose, S. (1999). Introduction: Agricultural Growth and Agrarian Change in West Bengal and Bangladesh. In B. Rogally, B. Harris-White, \& S. Bose, Sonar Bangla? Agricultural Growth and Agrarian Change in West Bengal and Bangladesh. New Delhi: Sage Publications.

Ruud, A. E. (1999). From Untouchable to Communist: Wealth, Power and Status among supporters of Communist Party (Marxist) in Rural West Bengal. In B. Rogally, B. HarrisWhite, \& S. Bose, Sonar Bangla? Agricultural Growth and Agrarian Change in West Bengal and Bangladesh (pp. 253-278). New Delhi: Sage.

Sinha, A. (2005). Regional Roots of Development Politics in India. Bloomington: Indiana.

Sivaramakrishnan, K. (2000). Crafting Public Sphere in Forests of West Bengal. American Ethnologist .

Smith, N. (1998). The Satanic Geographies of Globalization: Uneven Development in the 1990s. Public Culture 10 (1) , 169-189.

Webster, N. (1999). Institutions, Actors and Strategies in West Bengal's Rural Development-- A Study on Irrigation. In B. Rogaly, B. Harris-White, \& S. Bose, Sonar Bangla? Agricultural Growth and Agrarian Change in West Bengal and Bangladesh (pp.329-356) . New Delhi: Sage Publications. 